\title{
PENERAPAN METODE BERCERITA DALAM MENGEMBANGKAN MORAL DAN AGAMA ANAK USIA DINI
}

\author{
Dina Khairiyah ${ }^{1}$ \\ Email: Edinna.airi04@gmail.com
}

\begin{abstract}
ABSTRAK
Penerapan metode bercerita merupakan salah satu metode yang dapat mengembangkan beberapa aspek perkembangan anak usia dini, seperti perkembangan moral dan agama. Dengan penggunaan metode bercerita seorang guru dapat mengenalkan dasar-dasar moral dan agama pada anak usia dini. Pendekatan penelitian ini kami menggunakan kajian pustaka (library research) sebagai tempat atau sumber acuan. Tujuan yang ingin dicapai dalam penelitian ini adalah ingin mengetahui metode mengembangkan moral agama pada anak usia dini dengan metode cerita. Berdasarkan hasil penelitian, secara umum metode bercerita untuk mengembangkan potensi moral dan agama anak didik ialah dengan menggunakan metode membaca langsung dari buku cerita, bercerita dengan menggunakan ilustrasi gambar dari buku, menceritakan dongeng, bercerita dengan menggunakan papan flanel, bercerita dengan menggunakan media boneka, dramatisasi suatu cerita, dan bercerita sambil memainkan jari-jari tangan. Isi dalam cerita harus mengandung aspek religius, aspek pedagogis, dan aspek psikologis yaitu berisi materi cerita tentang kisah nabi, sahabat, ulama, dan orang-orang sholeh.
\end{abstract}

Kata kunci: Metode Bercerita, Perkembangan Moral dan Agama.

\begin{abstract}
The application of the story-telling method is one method that can develop several aspects of early childhood development, such as moral and religious development. By using the story-telling method a teacher can introduce the moral and religious foundations in early childhood. Our research approach uses library research as a place or source of reference. The aim of this research is to find out the method of developing religious morals in early childhood with the story method. Based on the results of the study, in general the method of storytelling to develop the moral and religious potential of students is to use the method of reading directly from story books, telling stories using picture illustrations from books, telling stories, telling stories using flannel boards, telling stories using puppet media, dramatization a story, and a story while playing fingers. The contents in the story must contain religious aspects, pedagogical aspects, and psychological aspects, which contain material stories about the stories of prophets, friends, scholars, and pious people
\end{abstract}

Keywords: Storytelling Method, Moral and Religious Development.

${ }^{1}$ Dosen Institut Agama Islam Negeri Padangsidimpuan 


\section{PENDAHULUAN}

Perkembangan moral anak sangat penting untuk diperhatikan sejak usia dini. Nabi Muhammad SAW merupakan nabi terakhir yang membawa risalah untuk umat manusia, sebagai rasul yang terakhir beliau dianugrahi banyak kelebihan serta cobaan yang banyak pula, sehingga untuk menyebarkan ajaran Islam yang ia bawa, beliau memberikan banyak contoh metode yang dapat digunakan dalam mengajarkan ilmu-ilmu keislaman supaya dapat diterima dan difahami dengan mudah. Dan diantara metode yang pernah dipakai oleh nabi ialah metode pengajaran dengan cara bercerita tentang kisah-kisah yang dapat diambil hikmah dan pelajaran dari kisah atau cerita tersebut.

Metode bercerita merupakan suatu metode yang mempunyai daya tarik yang menyentuh perasaan anak. Ajaran Islam yang dibawa oleh Nabi Muhammad SAW sangat menyadari akan adanya sifat alamiah manusia untuk menyenangi cerita yang pengaruhnya besar terhadap perasaan. Sehingga oleh karenanya metode kisah atau cerita ini dapat dijadikan sebagai salah satu teknik pendidikan. Dunia kehidupan peserta didik tidak akan lepas dari lingkungan keluarga, sekolah, dan luar sekolah. Sehingga sudah selayaknya kegiatan bercerita harus diusahakan menjadi pengalaman yang bersifat unik dan menarik yang menggetarkan perasaan anak dan memotivasi anak untuk mengikuti cerita sampai tuntas.

\section{KAJIAN TEORITIK}

\section{A. Metode Bercerita}

Metode bercerita secara etimologi, metode berasal dari kata method yang artinya suatu cara kerja yang sistematis untuk memudahkan pelaksanaan kegiatan dalam mencapai suatu tujuan. Metode pembelajaran dapat pula diartikan sebagai suatu cara yang sistematis untuk melakukan aktivitas atau kegiatan pembelajran yang tujuannya mempermudah dalam mencapai tujuan pembelajaran yang diinginkan. ${ }^{2}$ Cerita merupakan salah satu bentuk sastra yang memiliki keindahan dan kenikmatan tersendiri. Akan menyenangkan bagi anak-anak maupun orang dewasa, jika pengarang, pendongeng dan penyimaknya sama-sama baik.

\footnotetext{
${ }^{2}$ Muhammad Fadlillah, Desain Pembelajaran Paud, (Jogyakarta: Ar-Ruzz Media, 2012), h. 161.
} 
Cerita adalah salah satu bentuk sastra yang bisa dibaca atau hanya didengar oleh orang yang tidak membaca. $^{3}$

Jadi metode cerita adalah suatu teknik untuk memberikan cerita kepada anak-anak berbentuk sastra yang memiliki keindahan dan kenikmatan tersendiri untuk mengkomunikasikan pesan-pesan cerita yang mengandung unsur etika, moral, maupun nilainilai agama. Selain dapat bermanfaat untuk pengembangan kepribadian, akhlak maupun moral anak, mendongeng dapat juga bermanfaat untuk meningkatkan pengembangan bahasa anak. Sejak dini anak memperoleh berbagai wawasan cerita yang memperkaya dan meningkatkan kemampuan kognitif, memori, kecerdasan, imajinasi dan kreativitas bahasa.

Tujuan metode bercerita adalah agar anak dapat membedakan perbuatan yang baik dan buruk sehingga dapat diaplikasikan dalam kehidupan sehari-hari. Dengan bercerita guru dapat menanamkan nilai-nilai Islam pada anak didik, seperti menunjukan perbedaan perbuatan baik dan buruk serta ganjaran dari setiap perbuatan. Menurut Asnelli Ilyas bahwa tujuan metode bercerita atau berkisah dalam pendidikan anak adalah menanamkan akhlak Islamiyah dan perasaan keTuhanan kepada anak dengan harapan melalui pendidikan dapat menggugah anak untuk senantiasa merenung dan berfikir sehingga dapat terwujud dalam kehidupan sehari-hari. ${ }^{4}$

Menurut Abdul Aziz, tujuan metode bercerita adalah sebagai berikut :

1. Melatih daya tangkap dan daya berpikir

2. Melatih daya konsentrasi

3. Menciptakan suasana menghibur anak dan menyenangkan mereka dengan bercerita yang baik

4. Membantu pengetahuan siswa secara umum

5. Mendidik akhlak ${ }^{5}$

Dengan demikian melalui metode bercerita maka anak-anak akan dapat menyerap pesan-pesan yang dituturkan melalui kegiatan bercerita tersebut, sehingga penuturan cerita yang sarat informasi atau nilai-nilai tersebut dapat dihayati anak dan diterapkan dalam

\footnotetext{
${ }^{3}$ Abdul Aziz Abdul Majid, Mendidik Dengan Cerita, (Bandung: PT Remaja Rosdakarya, 2008), h. 8.

${ }^{4}$ Asnelli Ilyas, Mendambakan Anak Soleh, (Bandung: Al-Bayan, 1997), Cet. Ke-2, h. 34.

${ }^{5}$ Abdul Aziz Abdul, Mendidik Dengan Cerita, (Bandung: Remaja Rosda Karya,2001), Cet.1, h. 6.
} 
kehidupan sehari-hari, serta dapat menumbuhkan rasa cinta anak-anak kepada Allah, Rosul dan Al-Qur'an.

Dalam pendidikan Islam, kisah mempunyai fungsi edukatif yang tidak dapat diganti dengan bentuk penyampaian lain selain bahasa. Hal ini disebabkan karena kisah Qur'ani dan nabawi mempunyai dampak psikologi dan edukatif yang sempurna, rapih dan jauh jangkauannya seiring dengan perkembangan zaman. Kemudian selain itu kisah edukatif juga sering kali melahirkan kehangatan perasaan dan vitalitas serta aktivitas di dalam jiwa, yang selanjutnya dapat memotivasi manusia untuk mengubah perilakunya dan memperbaharui tekadnya sesuai dengan tuntunan, pengarahan dan akhir kisah itu, serta pengambilan pelajaran darinya. ${ }^{6}$

Adapun Fungsi Metode Bercerita secara umum oleh kalangan ahli metodologi pendididkan disebutkan bahwa metode cerita berfungsi bukan hanya sebagai hiburan tetapi juga merupakan suatu cara yang dapat digunakan dalam mencapai sasaran-sasaran atau target pendidikan. Metode cerita dapat menjadikan suasana belajar menyenangkan dan menggembirakan dengan penuh dorongan dan motivasi sehingga pelajaran atau materi pendidikan itu dapat dengan mudah diberikan.

Dalam hal ini beberapa fungsi metode cerita yakni diantaranya :

1. Menanamkan nilai-nilai pendidikan yang baik

Melalui metode bercerita ini sedikit demi sedikit dapat ditanamkan hal-hal yang baik kepada anak didik, dapat berupa cerita para Rosul atau umat-umat terdahulu yang memiliki kepatuhan dan keteladanan. Cerita hendaknya dipilih dan disesuaikan dengan tujuan yang hendak dicapai dalam suatu pelajaran.

2. Dapat mengembangkan imajinasi anak

Kisah-kisah yang disajikan dalam sebuah cerita dapat membantu anak didik dalam mengembangkan imajinasi mereka. Dengan hasil imajinasinya diharapkan mereka mampu bertindak seperti tokoh-tokoh dalam cerita yang disajikan oleh guru.

\footnotetext{
${ }^{6}$ Ramyulis, Metodologi Pendidikan Islam, (Jakarta: Kalam Mulia, 2005), h. 258.
} 
3. Membangkitkan rasa ingin tahu

Mengetahui hal-hal yang baik adalah harapan dari sebuah cerita sehingga rasa ingin tahu tersebut membuat anak berupaya memahami isi cerita. Isi cerita yang dipahami tentu saja akan membawa pengaruh terhadap anak didik dalam menentukan sikapnya. ${ }^{7}$

4. Memahami konsep ajaran Islam secara emosional

Cerita yang bersumber dari Al-Qur'an dan kisah-kisah keluarga muslim diperdengarkan melalui cerita, diharapkan anak didik tergerak hatinya untuk mengetahui lebih banyak agamanya dan pada akhirnya terdorong untuk beramal di jalan lurus. ${ }^{8}$

\section{B. Perkembangan Moral dan Agama Anak Usia Dini}

Pengertian moral secara etimologis kata "moral" berasal dari bahasa latin "mos", yang artinya tata cara, adat istiadat atau kebiasaan, sedangkan jamaknya adalah "mores". Dalam arti adat istiadat, kata "moral" mempunyai arti yang sama dengan kata Yunani "ethos" yang berarti "etika". Dalam bahasa Arab kata "moral" berarti budi pekerti yang berarti kata ini sama dengan "akhlak", sedangkan dalam bahasa Indonesia kata "moral" dikenal dengan arti "kesusilaan". 9

Menurut Kamus Psikologi moral merupakan hal-hal dihubungkan patokan-patokan mengenai perilaku yang benar dan yang salah, sesuai dengan keyakinan-keyakinan etis pribadi atau kaidah-kaidah kelompok dan kaidah-kaidah sosial. ${ }^{10}$ Sedangkan menurut Driyarkara dalam bukunya Bambang Daroeso bahwa moral berarti nilai yang sebenarnya bagi manusia, itu artinya moral merupakan kesempurnaan sebagai manusia atau kesusilaan yaitu tuntutan kodrat manusia. ${ }^{11}$ Berdasarkan beberapa pendapat dapat disimpulkan bahwa moral merupakan tingkah laku manusia yang mendasarkan diri pada kesadaran dan terikat

${ }^{7}$ H. M. Arifin, Ilmu Pendidikan Islam, (Jakarta: Bumi Askara, 1999), Cet.1, h. 61.

${ }^{8}$ Bahroin s. Mendidik anak Saleh Melalui Metode Pendekatan seni Bermain, Cerita dan Menyanyi, (Jakarta: t.pn. 1995), Cet.1, h. 24.

${ }^{9}$ Najah As-Sabatin, Najah, Dasar-dasar Mendidik Anak usia 1-10 Tahun, terj. Yahya Abdurrahman, (Bogor: Al Azhar Freshzone, 2014), hlm. 132. Di dalam karya Asti Inawati, "Strategi Pengembangan Moral dan Nilai Agama Untuk Anak Usia Dini”, (Jurnal Pendidikan Anak, Vol.3 No.1 2017), h. 2.

${ }^{10}$ Denok Dwi Anggraini, "Peningkatan Pengembangan Nilai Agama Dan Moral Melalui Metode Bercerita", (Program Studi Pendidikan Guru Pendidikan Anak Usia Dini Fakultas Ilmu Pendidikan Universitas Trunojoyo Madura, Jurnal PG-PAUD Trunojoyo, Volume 2, Nomor 2, Oktober 2015). h. 4.

${ }^{11}$ Bambang Daroeso, Dasar Dan Konsep Pendidikan Moral Pancasila, (Semarang: Aneka Ilmu, 1989), h. 22 . 
oleh keharusan untuk mencapai tingkah laku yang baik sesuai dengan nilai serta norma yang berlaku dalam lingkungannya.

Agama adalah aturan dan wahyu Tuhan yang sengaja diturunkan agar manusia hidup teratur, damai, sejahtera, bermartabat, dan bahagia baik di dunia maupun di akhirat. Ajaran agama juga berisi seperangkat norma yang akan menghantarkan manusia pada suatu peradaban masyarakat madani. ${ }^{12}$ Pendapat tersebut dapat disimpulkan bahwa nilai agama merupakan keharusan yang berupa suatu ide yang memberi pedoman agama untuk ukuran manusia dalam hubungannya dengan Allah SWT, sesama manusia dan alam semesta.

Pendidikan moral dan nilai nilai agama termasuk dalam lingkup pendidikan agama Islam. Pendidikan agama Islam menurut Muhamad Kholid Fathoni yaitu usaha-usaha secara sistematis dan pragmatis dalam membantu anak didik agar mereka hidup sesuai dengan ajaran islam. ${ }^{13}$ Sedangkan menurut Abdul majid dan Dian Andayani dalam bukunya yang berjudul "Pendidikan Agama Islam Berbasis kompetensi" bahwa pendidikan agama Islam merupakan upaya sadar dan terencana dalam menyiapkan peserta didik untuk mengenal, memahami, menghayati hingga mengimani ajaran agama Islam yang dibarengi dengan tuntunan untuk menghormati penganut agama lain dalam hubungannya dengan kerukunan antar umat beragama hingga terwujud kesatuan dan persatuan bangsa. ${ }^{14}$

Berdasarkan pendapat para ahli di atas dapat disimpulkan pendidikan agama Islam adalah usaha sadar untuk menyiapkan siswa dalam meyakini, memahami, menghayati, dan mengamalkan agama Islam melalui kegiatan bimbingan, pengajaran dan latihan. Tujuan pendidikan moral pada umumnya untuk mengarahkan manusia agar bermoral (berbudi pekerti, berakhlak dan beretika), ${ }^{15}$ agar mampu menggunakan pengetahuan, mengkaji dan menginternalisasi serta mempersonalisasi nilai, mengembangkan keterampilan sosial yang memungkinkan tumbuh dan berkembangnya akhlak mulia serta mewujudkannya dalam

\footnotetext{
2008). h.7.3.

${ }^{12}$ Hidayat, O., S. Metode Pengembangan Moral dan Nilai-nilai Agama. (Jakarta: Universitas Terbuka.

${ }^{13}$ Muhamad K. Fathoni, Pendidikan Islam dan Pendidikan Nasional Paradigm Baru, (Jakarta: Direktorat Kelembagaan Agama Islam, 2005) h.39.

${ }^{14}$ Abdul Majid dan Andayani, Pendidikan Islam Berbasis Kompetensi, (Bandung:PT Remaja Rosdakarya, 2006), cet.3, h. 130.

${ }^{15}$ Nurul Zuriah, Pendidikan Moral Dan Budi Pekerti Dalam Perspektif Perubahan, (Jakarta: PT Bumi Aksara, 2008), cet.2, h.22.
} 
perilaku sehari-hari dalam berbagai kehidupan sosial budaya yang berbineka sepanjang hayat. ${ }^{16}$

\section{Ciri-ciri Perkembangan Moral dan Agama Anak Usia Dini}

Perkembangan moral dan agama pada anak terjadi secara bertahap-tahap sesuai usianya dengan bercirikan sebagai berikut: ${ }^{17}$

1. Umur $>2-3$ tahun

Pada umur ini anak mampu bersenandung lagu keagamaan, mengikuti bacaan doa/ berdoa sebelum dan sesudah melakukan kegiatan serta menirukan sikap berdoa, meniru gerakan beribadah, mendengarkan cerita sederhana tentang kebesaran tuhan, mengenal nama-nama Tuhan, merawat benda mainannya, mengucapkan salam, terima kasih, maaf dan kata-kata santun.

2. Umur $>3-4$ tahun

Pada umur ini anak sudah bisa mengikuti nyanyian lagu keagamaan, mengikuti bacaan doa dengan lengkap sebelum melakukan kegiatan dan menirukan sikap berdoa, menirukangerakan beribadah dengan tertib, menyayangi orang tua, guru, teman dan menyebutkan contoh ciptaan Tuhan secara sederhana.

3. Umur $>4-5$ tahun

Pada usia ini anak mampu menyanyikan lagu keagamaan, berdoa sebelum dan sesudah melakukan kegiatan dengan sikap berdoa, dapat melakukan gerakan beribadah, membedakan ciptaan tuhan dengan buatan manusia, mengenal / memahami sifat-sifat tuhan dan selalu mengucapkan salam dan terima kasih setelah menerima sesuatu.

4. Umur > 5-6 tahun

Anak pada usia ini mampu menyanyikan lagu keagamaan, selalu berdoa sebelum dan sesudah melakukan kegiatan yang dilakukan dengan sikap yang benar, dapat melakukan ibadah, membedakan ciptaan tuhan dengan buatan manusia, menyayangi semua ciptaan Tuhan dan menunjukkan perilaku memelihara ciptaan

\footnotetext{
${ }^{16}$ Mutiara Magta, "Pengaruh Metode Dongeng Interaktif Terhadap Karakter Anak pada Taman KanakKanak Kuncup Harapan Singaraja”, (e-Journal Pendidikan Anak Usia Dini Universitas Pendidikan Ganesha, Volume 5. No. 1. 2017), h.4.

${ }^{17}$ Zainal Aqib, Pedoman Teknis Penyelenggaraan PAUD, (Bandung: Nuansa Aulia, 2010), cet.2, h.47.
} 
tuhan, menunjukkan perilaku atas dasar keyakinan adanya Tuhan. Dan menolong teman, orang dewasa, menghargai teman serta tidak memaksakan kehendak.

Berdasarkan tahapan perkembangan moral agama pada anak di atas ditarik benang merahnya bahwa semakin bertambahnya usia perkembangan kecerdasan moral agamanya juga semakin matang. Maka dar itu sebagai orang tua atau pendidik harus memahami perkembangan anak. Agar anak dapat berkembang dengan baik.

\section{Metode Penelitian}

Berdasarkan jenis data yang digunakan dan tujuan penelitian yang akan dicapai, Metode yang digunakan dalam penelitian ini adalah metode deskriptif, pendekatan penelitian kajian pustaka (library research) sebagai tempat atau sumber acuan. Maka dari itu memupuk kemampuan memanfaatkan perpustakaan harus dimulai dengan mengenal organisasi dan jenis koleksi perpustakaan serta memiliki pengetahuan tentang buku-buku referensi yaitu mengenai ruang lingkup, isi susunannya. ${ }^{18}$ Sumber data dalam penelitian ini adalah koleksi buku-buku perpustakaan terdiri dari sumber primer dan sekunder. Pengumpulan data dilakukan dengan mencari data berupa catatan, transkrip buku, surat kabar dalam perpustakaan. Analisis data menggunakan teknik induktif dan content analysis.

\section{Hasil Pembahasan}

Berdasarkan hasil penelitian melalui beberapa kajian pustaka disebutkan bahwa salah satu unsur penting dalam upaya pembentukan moral dan agama anak usia dini melalui cerita adalah memilih tema cerita yang baik untuk disampaikan kepada anak. Berikut ini beberapa definisi mengenai tema adalah sebagai berikut:

Tema-tema yang terdapat di dalam cerita banyak dikenal oleh masyarakat dan tidak semuanya baik untuk diceritakan kepada anak-anak. Dan untuk dewasa ini sudah banyak cerita yang diterbitkan, diantara yang banyak itu pilih cerita yang baik dan berguna. Banyak tema cerita yang diterbitkan yang tidak memiliki pendidikan dan moral. Kisah-kisah yang ditulis hanya untuk merangsang emosi-emosi yang rendah. Tema cerita seperti ini, bukanlah patut disisikan

\footnotetext{
${ }^{18}$ Ahmad Tanzeh, Metode Penelitian Praktis, (Tulung Agung: P3M, 2004), h. 18.
} 
dalam memilih tema. Secara teoritis ada beberapa aspek yang harus dipertimbangkan dalam memilih tema cerita.

Aspek-aspek tersebut di antaranya adalah

a. Aspek Relegius (agama)

Dalam memilih tema cerita yang baik, aspek agama ini tidak dapat diabaikan mengingat tema cerita yang dipilih merupakan sarana pembentukan moral. Jika aspek agama ini kurang diperhatikan keberadaanya, maka dikhawatirkan anak akan memperoleh informasi-informasi yang temanya tidak baik, bahkan ada kemungkinan cerita yang demikian dapat merusak moral anak yang sudah baik. Bagi kalangan keluarga muslim tema cerita yang dipilih tidak hanya karena gaya ceritanya saja, melainkan harus sarat dengan nilai-nilai ajaran Islam. Kini upaya menenggelamkan pengaruh cerita yang temanya tidak baik dan dapat merusak aqidah dan akhlak anak. ${ }^{19}$

b. Aspek Pedagogis (Pendidikan).

Pertimbangan aspek pendidikan dalam memilih tema cerita juga penting, sehingga dari tema cerita diperoleh dua keuntungan, yaitu menghibur dan mendidik anak dalam waktu yang bersamaan. Disinilah letak peran pencerita untuk dapat memilih tema cerita dan menyampaikan pesan-pesan didaktis dalam cerita. Unsur mendidik, baik secara langsung ataupun tidak langsung terimplisit dalam tema dongeng. ${ }^{20}$

c. Aspek Psikologis

Mempertimbangkan aspek psikologis dalam memilih tema cerita sangat membantu perkembangan jiwa anak. Mengingat anak adalah manusia yang sedang berkembang. Maka secara kejiwaan tema ceritapun disesuaikan dengan kemampuan berfikir, kestabilan emosi, kemampuan berbahasa serta tahap perkembangan pengetahuan anak dalam mengahayati cerita tersebut. Cerita yang baik dapat mempengaruhi perkembangan anak. ${ }^{21}$

Penerapan metode cerita dalam mengembangkan moral dan agama anak usia dini dapat dilakukan dengan penggunaan berbagai media seperti:

\footnotetext{
${ }^{19}$ J. Abdullah, Memilih Dongeng Islami Pada Anak, ( Jakarta : Amanah, 1997), h. 2.

${ }^{20}$ Sugihastuti, Serba-serbi Cerita Anak-anak, (Jakarta : Pustaka Pelajar,1996), Cet.1, h. 35.

${ }^{21}$ Ibid
} 


\section{Membaca Langsung Dari Buku Cerita}

Teknik bercerita dengan membacakan langsung itu sangat bagus bila guru mempunyai puisi atau prosa itu di bacakan kepada anak TK. Ukuran kebagusan puisi atau prosa itu terutama ditekankan pada pesan-pesan yang disampaikan yang dapat ditangkap anak: memahami perbuatan itu salah dan perbuatan ini benar, atau hal ini bagus dan hal itu jelek, atau kejadian itu lucu, kejadian itu menarik, dan sebagainya.

2. Bercerita dengan Menggunakan Ilustrasi Gambar dari Buku

Bila cerita yang disampaikan kepada anak TK selalu panjanng dan terinci dengan menambahkan ilustrasi gambar dari buku yang dapat menarik perhatian anak,maka teknik bercerita ini akan berfungsi dengan baik. Mendengarkan cerita tanpa ilustrasi gambar menuntut pemusatan perhatian yang lebih besar dibandingkan bila anak mendengarkan cerita dari buku bergambar. Untuk menjadi seorang yang dapat bercerita dengan baik guru TK memerlukan persiapan dan latihan.Penggunaan ilustrasi gambar dalam bercerita dimaksudkan untuk memperjelas pesan-pesan yang dituturkan, dan untuk mengikat perhatian anak pada jalannya cerita.

\section{Menceritakan Dongeng}

Cerita dongeng merupakan bentuk kesenian yang paling lama. Mendongeng merupakan cara meneruskan warisan budaya dari satu generasi ke generasi yang berikutnya. Dongeng dapat dipergunakan untuk menyampaikan pesan-pesan kebajikan kepada anak. Oleh karena itu, seni dongeng perlu dipertahankan dari kehidupan anak.Banyak buku-buku dongeng yang bagus dapat dibeli di pasaran, tetapi guru TK yang kreatif dapat mencipta dongeng dari negara Antah Beratah yang sarat dengan nilai-nilai kebajikan.

\section{Bercerita Dengan Menggunakan Papan Flanel}

Guru dapat membuat papan flanel dengan melapisi seluas papan dengan kain flanel yang berwarna netral, misalnya warna abu-abu. Gambar tokoh-tokoh yang mewakili perwatakan dalam ceritanya digunting polanya pada kertas yang dibelakangnya dilapis dengan kertas goso yang paling halus untuk menempelkan pada papan flanel supaya dapat melekat.Gambar fotofoto itu dapat dibeli di pasaran atau dikreasi oleh guru, sesuai dengan tema dan pesan-pesan yang ingin disampaikan melalui bercerita. 
5. Bercerita dengan Menggunakan Media Boneka

Pemilihan bercerita dengan menggunakan boneka akan tergantung pada usia dan pengalaman anak. Biasanya boneka itu terdiri dari ayah, ibu, anak laki-laki dan anak perempuan, nenek, kakek dan bisa ditambahkan anggota keluarga yang lain. Boneka yang dibuat itu masing-masing menjukkan perwatakan pemegang peran tertentu.Misalnya, ayah yang penyabar, ibu yang cerewet, anak laki-laki yang pemberani, anak perempuan yang manja, dan sebagainya.

6. Dramatisasi Suatu Cerita

Guru dalam bercerita memainkan perwatakan tokoh-tokoh dalam suatu cerita yang disukai anak dan merupakan daya tarik yang bersifat universal. Cerita anak-anak yang disukai seperti Timun Mas, si Kancil mencuri ketimun, dan sebagainya.

\section{Bercerita Sambil Memainkan Jari-jari Tangan}

Bercerita sambil memainkan jari tangan seperti dengan menggunakan sepuluh jari tangan, tangan tersembunyi, mengatupkan jari tangan yang satu dengan yang lain, mengangkat jari tangan, menurunkan jari tangan, menyilangkan jari tangan dan lain-lain. ${ }^{22}$

Adapun jenis cerita untuk mengembangkan moral dan agama pada anak usia dini menurut materi yang disampaikan kepada anak-anak dapat dikategorikan dalam beberapa macam, antara lain:

a. Cerita para nabi

Materi cerita berisi kisah-kisah 25 nabi utusan Allah, mulai dari kelahiran, perjuangan dalam menjalankan tugas, sampai wafatnya. Materi cerita ini hendaknya menjadi materi utama yang disampaikan kepada anak-anak. Dalam cerita ini, pembawa cerita dapat sekaligus mengajarkan nilai-nilai akidah dan akhlak al-karimah kepada anakanak.

b. Cerita para sahabat, ulama, dan orang-orang saleh

Materi cerita berisi kisah-kisah para sahabat, ulama, dan orang-orang saleh yang dapat dijadikan suri teladan untuk lebih meningkatkan ketakwaan dankeimanan serta akhlak al-karimah. Misalnya: cerita khulafaur rasyidin, walisongo. ${ }^{23}$

\footnotetext{
${ }^{22}$ Moeslichatoen R. Metode Pengajaran di Taman Kanak-kanak(Jakarta: Rieneka Cipta,2004), h. 157-166.

${ }^{23}$ Mohammad Fauziddin, Pemebelajaran Paud, (Bandung: PT Remaja Rosdakarya, 2014), h 19-20.
} 
Adapun teknik penggunaan dari masing-masing bentuk metode bercerita tersebut dapat menggunakan alat peraga langsung atau tidak menggunakan alat peraga.

\section{Kesimpulan}

Perkembangan moral dan agama anak merupakan salah satu aspek perkembangan yang perlu diperhatikan sejak dini. Untuk mengembangkan moral dan agama anak usia dini seorang guru dapat menerapkan metode bercerita. Pemilihan tema cerita sangat penting untuk diperhatikan oleh setiap guru dalam menyampaikan cerita. Tema cerita yang dipilih harus sesuai dengan perkembangan anak, sehingga dapat menstimulasi imajinasi dan pemikiran anak. Tema cerita yang digunakan harus mengandung aspek religius, pendidikan, dan psikologis.

Penerapan metode bercerita dapat lebih efektif apabila menggunakan beberapa media diantaranya: membaca langsung dari buku cerita, bercerita dengan menggunakan ilustrasi gambar dari buku, menceritakan dongeng, bercerita dengan menggunakan papan flanel, bercerita dengan menggunakan media boneka, dramatisasi suatu cerita, dan bercerita sambil memainkan jari-jari tangan.

\section{DAFTAR PUSTAKA}

Aqib, Zainal, Pedoman Teknis Penyelenggaraan PAUD, Bandung: Nuansa Aulia, 2010.

Anggraini, Denok Dwi,'Peningkatan Pengembangan Nilai Agama Dan Moral Melalui Metode Bercerita", Program Studi Pendidikan Guru Pendidikan Anak Usia Dini Fakultas Ilmu Pendidikan Universitas Trunojoyo Madura, Jurnal PG-PAUD Trunojoyo, Volume 2, Nomor 2, Oktober 2015.

Arifin, H. M, Ilmu Pendidikan Islam, Jakarta: Bumi Askara, 1999.

Abdullah, J. Memilih Dongeng Islami Pada Anak, Jakarta : Amanah, 1997.

Bahroins, Mendidik anak Saleh Melalui Metode Pendekatan seni Bermain, Cerita dan Menyanyi, Jakarta: t.pn. 1995.

Daroeso, Bambang, Dasar Dan Konsep Pendidikan Moral Pancasila, Semarang: Aneka Ilmu, 1989.

Fauziddin, Mohammad, Pemebelajaran Paud, Bandung: PT Remaja Rosdakarya, 2014.

Fadlillah, Muhammad, Desain Pembelajaran Paud, Jogyakarta: Ar-Ruzz Media, 2012. 
Fathoni, Muhamad K., Pendidikan Islam dan Pendidikan Nasional Paradigm Baru, Jakarta: Direktorat Kelembagaan Agama Islam, 2005.

Hidayat, O, S. Metode Pengembangan Moral dan Nilai-nilai Agama. Jakarta: Universitas Terbuka. 2008.

Inawati, Asti, Strategi Pengembangan Moral dan Nilai Agama Untuk Anak Usia Dini, Jurnal Pendidikan Anak, Vol.3 No.1 2017.

Ilyas, Asnelli, Mendambakan Anak Soleh, Bandung: Al-Bayan, 1997.

Majid, Abdul dan Andayani, Pendidikan Islam Berbasis Kompetensi, Bandung:PT Remaja Rosdakarya, 2006.

Magta, Mutiara, ’Pengaruh Metode Dongeng Interaktif Terhadap Karakter Anak pada Taman Kanak-Kanak Kuncup Harapan Singaraja", e-Journal Pendidikan Anak Usia Dini Universitas Pendidikan Ganesha, Volume 5. No. 1. 2017.

Moeslichatoen R. Metode Pengajaran di Taman Kanak-kanak, Jakarta: Rieneka Cipta,2004.

Majid, Abdul Aziz Abdul, Mendidik Dengan Cerita, Bandung: PT Remaja Rosdakarya, 2008.

Najah, As-Sabatin, Dasar-dasar Mendidik Anak usia 1-10 Tahun, terj. Yahya Abdurrahman, Bogor: Al Azhar Freshzone, 2014.

Ramyulis, Metodologi Pendidikan Islam, Jakarta: Kalam Mulia, 2005.

Sugihastuti, Serba-serbi Cerita Anak-anak, Jakarta : Pustaka Pelajar, 1996.

Tanzeh, Ahmad, Metode Penelitian Praktis, Tulung Agung: P3M, 2004.

Zuriah, Nurul, Pendidikan Moral Dan Budi Pekerti Dalam Perspektif Perubahan, Jakarta: PT Bumi Aksara, 2008. 